\title{
Combined toxicity of copper and cadmium to six rice genotypes (Oryza sativa L.)
}

\author{
HUANG Yizong*, HU Ying, LIU Yunxia \\ Research Center for Eco-Environmental Sciences, Chinese Academy of Sciences, Beijing 100085, China. E-mail: hyz@ rcees.ac.cn
}

Received 22 May 2008; revised 08 August 2008; accepted 01 September 2008

\begin{abstract}
Accumulations of copper $(\mathrm{Cu})$ and cadmium (Cd) in six rice cultivars (94D-22, 94D-54, 94D-64, Gui630, YY-1, and KY1360) were evaluated through exposure to heavy metal contamination $(100 \mathrm{mg} / \mathrm{kg} \mathrm{Cu}, 1.0 \mathrm{mg} / \mathrm{kg} \mathrm{Cd}$, and $100 \mathrm{mg} / \mathrm{kg} \mathrm{Cu}+1.0 \mathrm{mg} / \mathrm{kg} \mathrm{Cd}) \mathrm{in} \mathrm{a}$ greenhouse. The dry weights of shoot and root, concentrations of $\mathrm{Cu}$ and $\mathrm{Cd}$ in plant tissues and the $\mathrm{Cu}, \mathrm{Cd}, \mathrm{P}, \mathrm{Fe}$ concentrations in the root surface iron plaques were analyzed eight weeks later after treatment. The results indicated that the plant biomass was mainly determined by rice genotypes, not $\mathrm{Cu}$ and $\mathrm{Cd}$ content in soil. Separated treatment with $\mathrm{Cu} / \mathrm{Cd}$ increased each metal level in shoot, root and iron plaques. Soil $\mathrm{Cu}$ enhanced $\mathrm{Cd}$ accumulation in tissues. In contrast, $\mathrm{Cu}$ concentrations in shoot and root was unaffected by soil Cd. Compared to single metal contamination, combined treatment increased Cd content by $110.6 \%, 77.0 \%$, and $45.2 \%$ in shoot, and by $112.7 \%, 51.2 \%$ and $18.4 \%$ in root for Gui630, YY-1, and KY1360, respectively. The content level of Cu or Cd in root surface iron plaques was not affected by their soil content. $\mathrm{Cu}$ promoted Fe accumulation in iron plaques, while $\mathrm{Cd}$ has no effect on $\mathrm{P}$ and Fe accumulation in it. The translocation of $\mathrm{Cu}$ and $\mathrm{Cd}$ from iron plaques to root and shoot was also discussed. These results might be beneficial in selecting cultivars with low heavy metal accumulation and designing strategies for soil bioremediation.
\end{abstract}

Key words: $\mathrm{Cu}$; $\mathrm{Cd}$; combined contamination; soil; uptake; accumulation; root surface iron plaques

DOI: $10.1016 / \mathrm{S} 1001-0742(08) 62320-7$

\section{Introduction}

To meet the needs of the rapidly increasing population, many countries have expanded tremendously the development of land and mineral resources. The emergence of many refinery factories has caused serious environmental problems including soil heavy metal contamination. The most concerned heavy metals are $\mathrm{Cd}, \mathrm{Pb}, \mathrm{As}, \mathrm{Hg}, \mathrm{Cu}, \mathrm{Cr}$, etc. According to the US National Priority List (NPL), for 1200 soil samples, $63 \%$ of them contain $\mathrm{Pb}, \mathrm{Cr}, \mathrm{Cd}$ and $\mathrm{Cu}$ at $15 \%, 11 \%, 8 \%$ and $7 \%$, respectively (Hazardous Waste Consultant, 1996). In China, $\mathrm{Cd}, \mathrm{As}, \mathrm{Pb}, \mathrm{Hg}$ and $\mathrm{Zn}$ have contaminated about $2.0 \times 10^{7} \mathrm{hm}^{2}$ which comprises $1 / 5$ of the arable land. The industrial wastewater irrigation accounts for $3.3 \times 10^{7} \mathrm{hm}^{2}$ (Chen, 1996). Heavy metals in the soil can subsequently enter food chain and are considered hazardous to human health.

$\mathrm{Cd}$ is a non-essential element and can be absorbed easily by plants. Therefore, it is more toxic to plants than other metals such as $\mathrm{Ni}, \mathrm{Cu}, \mathrm{Zn}$ and $\mathrm{Pb}$ (Balsberg, 1989). $\mathrm{Cu}$ is an essential element, but the overdose can adversely affect plant growth (Cao et al., 2000; Chatterjee and Chatterjee, 2000).

The knowledge of heavy metals biological toxicity on plant, especially on growth and development, their up-

\footnotetext{
* Corresponding author. E-mail: hyz@rcees.ac.cn
}

take and accumulation in plants and their translocation dynamics, is very important for agricultural production and environmental and human health protection. Extensive research works have been performed in the related field. However, previous work is mostly about single metal contamination (Das et al., 1997; Tang and Robson, 2000; Sarret et al., 2002; Carrier et al., 2003; Murakami et al., 2007). The real situation is that soil is often contaminated with several heavy metals. Therefore, the increasing attention have been paid on the combined contamination (Stewart and Malley, 1999; Franklin et al., 2002; Wang, 2003; Ali et al., 2004; Alexander et al., 2006).

Response to soil heavy metal contamination is depended on the species, or even genotypes-specific. For example, compared to spring wheat, barley, corn and oats, the hard wheat, sunflower and flax are considered high Cd accumulation crops (Grant et al., 1999). Difference in heavy metal uptake and accumulation among cultivars are observed in soybean (Boggess et al., 1978), corn (Florijn and van Beusichem, 1993), wheat (Oliver et al., 1994; Zhang et al., 2000), barley (Wu and Zhang, 2002), potato (McLaughlin et al., 1994) and lettuce (John and Laerhoven, 1976; Costa and Morel, 1994). The Cd accumulation in crops varied with genotypic difference has also been reported by Grant et al. (1999). Moreover, Liu et al. (2006) investigated arsenic sequestration in iron plaque and its accumulation 
and speciation in different rice cultivars (94D-22, 94D-54, 94D-64, Gui630, YY-1, and KY1360).

Rice is one major grains crop, and $90 \%$ of production occur in Asia. Although soil heavy metal contamination can seriously affect the yield quantitatively and qualitatively, very few studies have been conducted on characterizing different rice cultivars grown on contaminated soil. The current research is expected to provide information for selecting rice cultivars which has low copper and cadmium accumulation capacity.

\section{Materials and methods}

\subsection{Soil preparation}

Soil samples were collected from paddy field at 0-20 $\mathrm{cm}$ depth in the vicinity of Huzhou, Zhejiang Province, China. The soil was air-dried, ground into fine powder and passed through a 1-mm sieve for growth experiment in the future. The physiological and chemical properties of soil were determined according to the methods described by $\mathrm{Lu}$ (1999). Soil $\mathrm{pH}$ is 6.3 determined from the water extracts (soil:water, 1:2.5, W/W). Organic matter content is 43.6 $\mathrm{g} / \mathrm{kg}$. Cation exchange capacity (CEC) is $11.2 \mathrm{cmol} / \mathrm{kg}$, and $\mathrm{Cu}$ and $\mathrm{Cd}$ content are 40.0 and $0.5 \mathrm{mg} / \mathrm{kg}$, respectively. Soil particles comprise $11.6 \%$ clay, $38.0 \%$ silty particle and $50.4 \%$ sandy particle.

\subsection{Plant culture}

Six rice (Oryza sativa L.) genotypic cultivars of 94D22, 94D-54, 94D-64, Gui630, YY-1, and KY1360 were provided by Prof. Li Damo in the Subtropical Agricultural Ecological Institute of Chinese Academy of Sciences. Surface sterilization was conducted by soaking the seeds in $10 \% \mathrm{H}_{2} \mathrm{O}_{2}$ for $10 \mathrm{~min}$, followed by washing with deionized water three times. Germinated seeds were grown in perlite for 2-3 week until 3-4 leaf stage. The seedling growth conditions are $28^{\circ} \mathrm{C} / 20^{\circ} \mathrm{C}$ (day/night), $14 \mathrm{~h} / 10 \mathrm{~h}$ photoperiod with light intensity at $260-350 \mathrm{mmol} /\left(\mathrm{m}^{2} \cdot \mathrm{s}\right)$ and $60 \%-70 \%$ relative humidity.

For heavy metal application, stock solutions of $\mathrm{CuSO}_{4}$ and $\mathrm{CdCl}_{2}$ were mixed with $1000 \mathrm{~g}$ soil at the following four levels: (1) 0 (CK); (2) $100 \mathrm{mg} \mathrm{Cu}$ as $\mathrm{CuSO}_{4}(\mathrm{Cu})$; (3) $1.0 \mathrm{mg} \mathrm{Cd}$ as $\mathrm{CdCl}_{2}$ (Cd); (4) $100 \mathrm{mg} \mathrm{Cu}$ as $\mathrm{CuSO}_{4}+1.0$ mg $\mathrm{Cd}$ as $\mathrm{CdCl}_{2}(\mathrm{Cu}+\mathrm{Cd})$. $\mathrm{Cu}$ and $\mathrm{Cd}$ were dissolved in water and mixed into soil and then wetted with deinonized water for one month to let reach equilibrium before used as potting mixture. Each Polyvinyl Chloride (PVC) pot (7 cm width $\times 25 \mathrm{~cm}$ height) was filled with $1000 \mathrm{~g}$ soil and planted with a single seedling, and fertilized with urea $(0.428 \mathrm{~g} / \mathrm{kg})$ and potassium sulphate $(0.247 \mathrm{~g} / \mathrm{kg})$. Each treatment was repeated 4 times and totally was 96 pots. Deionized water was applied every two days to maintain waterlogging condition. The plants were grown for 8 weeks at $25-30^{\circ} \mathrm{C}$ and light intensity was $500-1100$ $\mathrm{mmol} /\left(\mathrm{m}^{2} \cdot \mathrm{s}\right)$.

\subsection{Plant tissue analysis}

After the harvest, the rice root surface iron plaques were extracted with dithionite-citrate-bicarbonate (DCB)
(Meharg and Jardine, 2003). Briefly, roots were rinsed with deionized water before soaked in a $40-\mathrm{mL}$ solution consisting $0.03 \mathrm{~mol} / \mathrm{L}$ sodium citric $\left(\mathrm{Na}_{3} \mathrm{C}_{6} \mathrm{H}_{5} \mathrm{O}_{7} \cdot 2 \mathrm{H}_{2} \mathrm{O}\right)$ and $0.125 \mathrm{~mol} / \mathrm{L}$ sodium carbonate $\left(\mathrm{NaHCO}_{3}\right)$ for $10 \mathrm{~min}$, and then continued for additional $1 \mathrm{~h}$ after adding $1 \mathrm{~g}$ $\mathrm{Na}_{2} \mathrm{~S}_{2} \mathrm{O}_{4}$. Eventually, root was washed several times with deionized water and the collected liquid was diluted to 100 $\mathrm{mL}$. The solution was filtered and stored until analysis. Dry weight (dw) of root and shoot was determined after oven drying at $70^{\circ} \mathrm{C}$ for $72 \mathrm{~h}$.

Plant samples were all digested prior to mineral analysis. The shoot and root tissues were grounded into fine power. A $0.25-\mathrm{g}$ of sample was put into digestion tube and then $5 \mathrm{~mL}$ nitric acid $\left(\mathrm{HNO}_{3}\right)$ was added. After boiling at $90^{\circ} \mathrm{C}$ for $1 \mathrm{~h}$, the temperature was raised to $160^{\circ} \mathrm{C}$ and all samples were melted. The digestion solution was added to $50 \mathrm{~mL}$ with ultrapure water. Calibration was conducted using contaminated tea leaf (GBW 07605(GSV-4) provided by the China National Standard Material Center to ensure that the recollection ratio reached $95 \% . \mathrm{Cu}, \mathrm{Cd}, \mathrm{Fe}$ and $\mathrm{P}$ concentrations were determined using ICP-MS (Agilent 7500i, USA).

\subsection{Data analysis}

Iron plaque-to-shoot transfer factors $\left(F_{\text {shoot }}\right)$ and iron plaque-to-root transfer factors $\left(F_{\text {root }}\right)$ were calculated as follows:

$$
\begin{gathered}
F_{\text {shoot }}=\frac{C_{\text {shoot,dry }}}{C_{\text {iron,plaque }}} \\
F_{\text {root }}=\frac{C_{\text {root,dry }}}{C_{\text {iron,plaque }}}
\end{gathered}
$$

where, $C_{\text {shoot,dry }}$ and $C_{\text {root,dry }}$ are shoot and root $\mathrm{Cu}$ or $\mathrm{Cd}$ concentration on dw basis, and $C_{\text {iron,plaque is the corre- }}$ sponding concentration of $\mathrm{Cu}$ or $\mathrm{Cd}$ in iron plaque.

All data were subjected to two-way analysis of variance (ANOVA) performed using the Microsoft Windows-based Genstat package (6th ed., NAG Ltd., England).

\section{Results}

\subsection{Plant biomass}

The dry weight of shoot and root differ greatly among genotypic cultivars $(p<0.001)$, with KY1360 being the highest and relatively lower for 94D-22, 94D-54, 94D-64 (Table 1). Soil $\mathrm{Cu}$ and $\mathrm{Cd}$ had very slight effect on root $\mathrm{dw}$, but shoot dw showed some reduction in $\mathrm{Cu}$ treated soil.

\section{2 $\mathrm{Cu}$ accumulation in plant tissues}

Adding $\mathrm{Cu}$ into soil generally induced its accumulation in shoot and root, however, the extent of changes depends on the cultivars $(p<0.001)$. Compared to control, 100 $\mathrm{mg} / \mathrm{kg} \mathrm{Cu}$ treatment raised $\mathrm{Cu}$ concentrations by 3.0-4.6 fold in root and 1.2-2.9 fold in shoot (Table 2). KY1360 had the highest increment in root $\mathrm{Cu}$ while such change in shoot was observed in KY1360 and YY-1C. Although adding $\mathrm{Cd}$ into soil somehow reduced $\mathrm{Cu}$ content in shoot and root, but to a lesser degree than statistically significant. 
Table 1 Biomass of different rice genotypes grown at $\mathrm{Cu}$ and $\mathrm{Cd}$ contaminated soils (g/pot)

\begin{tabular}{|c|c|c|c|c|c|c|c|c|}
\hline \multirow[t]{2}{*}{ Genotype } & \multicolumn{4}{|c|}{ Shoot } & \multicolumn{4}{|c|}{ Root } \\
\hline & CK & $\mathrm{Cu}$ & $\mathrm{Cd}$ & $\mathrm{Cu}+\mathrm{Cd}$ & $\mathrm{CK}$ & $\mathrm{Cu}$ & $\mathrm{Cd}$ & $\mathrm{Cu}+\mathrm{Cd}$ \\
\hline $94 \mathrm{D}-22$ & $3.15 \pm 0.24$ & $2.73 \pm 0.19$ & $2.56 \pm 0.26$ & $2.65 \pm 0.51$ & $0.86 \pm 0.06$ & $0.81 \pm 0.07$ & $0.70 \pm 0.06$ & $0.80 \pm 0.15$ \\
\hline 94D-54 & $2.97 \pm 0.14$ & $2.15 \pm 0.24$ & $3.20 \pm 0.35$ & $2.52 \pm 0.23$ & $1.00 \pm 0.07$ & $0.86 \pm 0.10$ & $1.32 \pm 0.16$ & $0.88 \pm 0.07$ \\
\hline 94D-64 & $2.92 \pm 0.26$ & $3.14 \pm 0.23$ & $2.83 \pm 0.25$ & $2.98 \pm 0.33$ & $1.00 \pm 0.07$ & $1.11 \pm 0.12$ & $1.00 \pm 0.06$ & $1.12 \pm 0.13$ \\
\hline Gui630 & $3.30 \pm 0.36$ & $3.28 \pm 0.36$ & $3.52 \pm 0.44$ & $3.12 \pm 0.19$ & $1.41 \pm 0.11$ & $1.46 \pm 0.15$ & $1.51 \pm 0.14$ & $1.42 \pm 0.10$ \\
\hline YY-1 & $3.33 \pm 0.31$ & $2.53 \pm 0.15$ & $2.59 \pm 0.17$ & $2.71 \pm 0.35$ & $1.14 \pm 0.08$ & $0.86 \pm 0.02$ & $0.93 \pm 0.06$ & $0.99 \pm 0.08$ \\
\hline KY1360 & $4.28 \pm 0.41$ & $3.64 \pm 0.15$ & $3.97 \pm 0.47$ & $3.95 \pm 0.27$ & $1.28 \pm 0.11$ & $1.15 \pm 0.04$ & $1.19 \pm 0.14$ & $1.32 \pm 0.12$ \\
\hline \multicolumn{9}{|c|}{ Analysis of variance } \\
\hline $\mathrm{Cu}$ & \multicolumn{4}{|c|}{$p<0.05$} & \multicolumn{4}{|c|}{ NS } \\
\hline $\mathrm{Cd}$ & \multicolumn{4}{|c|}{ NS } & \multicolumn{4}{|c|}{ NS } \\
\hline Genotype & \multicolumn{4}{|c|}{$p<0.001$} & \multicolumn{4}{|c|}{$p<0.001$} \\
\hline $\mathrm{Cu} \times \mathrm{Cd}$ & \multicolumn{4}{|c|}{ NS } & \multicolumn{4}{|c|}{ NS } \\
\hline Cu×genotype & \multicolumn{4}{|c|}{ NS } & \multicolumn{4}{|c|}{ NS } \\
\hline $\mathrm{Cd} \times$ genotype & \multicolumn{4}{|c|}{ NS } & \multicolumn{4}{|c|}{ NS } \\
\hline
\end{tabular}

Data are expressed as mean \pm standard errors; NS indicates the treatment effect not significant at the 0.05 level; $\mathrm{CK}$ is control, without $\mathrm{Cu}$ and $\mathrm{Cd}$. These parameters express the same meaning in following tables.

Table 2 Concentrations of $\mathrm{Cu}$ in shoot and root of different rice genotypes grown in $\mathrm{Cu}$ and $\mathrm{Cd}$ contaminated soils (mg/kg)

\begin{tabular}{|c|c|c|c|c|c|c|c|c|}
\hline \multirow[t]{2}{*}{ Genotype } & \multicolumn{4}{|c|}{ Shoot } & \multicolumn{4}{|c|}{ Root } \\
\hline & CK & $\mathrm{Cu}$ & $\mathrm{Cd}$ & $\mathrm{Cu}+\mathrm{Cd}$ & CK & $\mathrm{Cu}$ & $\mathrm{Cd}$ & $\mathrm{Cu}+\mathrm{Cd}$ \\
\hline 94D-22 & $14.44 \pm 2.81$ & $31.32 \pm 4.87$ & $11.37 \pm 0.82$ & $31.48 \pm 5.69$ & $21.21 \pm 3.55$ & $112.28 \pm 13.16$ & $24.33 \pm 1.80$ & $97.39 \pm 9.60$ \\
\hline 94D-54 & $9.46 \pm 0.29$ & $28.34 \pm 1.05$ & $10.14 \pm 0.76$ & $18.95 \pm 2.16$ & $19.12 \pm 0.80$ & $76.03 \pm 4.15$ & $15.67 \pm 0.49$ & $84.47 \pm 2.58$ \\
\hline 94D-64 & $9.63 \pm 0.53$ & $24.29 \pm 1.73$ & $9.36 \pm 0.49$ & $18.73 \pm 1.02$ & $19.31 \pm 1.94$ & $76.59 \pm 6.35$ & $17.61 \pm 0.80$ & $73.25 \pm 1.26$ \\
\hline Gui630 & $11.81 \pm 0.24$ & $34.40 \pm 4.51$ & $8.98 \pm 0.74$ & $33.24 \pm 3.31$ & $13.55 \pm 0.55$ & $70.11 \pm 5.30$ & $11.26 \pm 0.47$ & $66.06 \pm 5.18$ \\
\hline YY-1 & $7.91 \pm 0.52$ & $30.92 \pm 2.62$ & $7.74 \pm 0.48$ & $26.54 \pm 2.04$ & $15.69 \pm 1.86$ & $71.52 \pm 5.65$ & $13.86 \pm 1.35$ & $71.25 \pm 6.90$ \\
\hline KY1360 & $7.14 \pm 0.23$ & $27.80 \pm 2.04$ & $9.97 \pm 0.88$ & $20.58 \pm 2.22$ & $15.37 \pm 2.18$ & $86.76 \pm 1.95$ & $19.27 \pm 2.29$ & $71.31 \pm 7.60$ \\
\hline \multicolumn{9}{|c|}{ Analysis of variance } \\
\hline $\mathrm{Cu}$ & \multicolumn{4}{|c|}{$p<0.001$} & \multicolumn{4}{|c|}{$p<0.001$} \\
\hline $\mathrm{Cd}$ & \multicolumn{4}{|c|}{ NS } & \multicolumn{4}{|c|}{ NS } \\
\hline Genotype & \multicolumn{4}{|c|}{$p<0.001$} & \multicolumn{4}{|c|}{$p<0.001$} \\
\hline $\mathrm{Cu} \times \mathrm{Cd}$ & \multicolumn{4}{|c|}{ NS } & \multicolumn{4}{|c|}{ NS } \\
\hline Cu $\times$ genotype & \multicolumn{4}{|c|}{ NS } & \multicolumn{4}{|c|}{$p<0.01$} \\
\hline Cd $\times$ genotype & \multicolumn{4}{|c|}{ NS } & \multicolumn{4}{|c|}{ NS } \\
\hline
\end{tabular}

This result indicates that $\mathrm{Cd}$ has negligible influence on $\mathrm{Cu}$ accumulation.

\subsection{Cd accumulation in plant tissues}

Similarly, Cd concentration in shoot and root was higher in $\mathrm{Cd}$ treated soils $(p<0.001)$, however, inter-cultivar difference was not as significant as for $\mathrm{Cu}$ (Table 3). Compared to control, shoot and root $\mathrm{Cd}$ concentrations increased by 4.3-10.2 fold in shoot and 6.7-12.9 fold in root with $1.0 \mathrm{mg} / \mathrm{kg} \mathrm{Cd}$. KY1360 has the highest $\mathrm{Cd}$ content. Additional application of $\mathrm{Cu}$ into $\mathrm{Cd}$ treated soil enhanced $\mathrm{Cd}$ accumulation obviously $(p<0.001)$, suggesting an interactive relationship between these. However, the extent of interaction is dependent on the cultivars. Shoot Cd concentrations for Gui630, YY-1, 94D-22 and KY1360 in $\mathrm{Cu}+\mathrm{Cd}$ combined treatment was respectively $110.6 \%$, $77.0 \%, 58.6 \%$, and $45.2 \%$ higher than that in $\mathrm{Cd}$ single application. Root $\mathrm{Cd}$ concentration was increased more pronounced in Gui630 (112.7\%), YY-1 (51.2\%), KY1360 (18.4\%), and 94D-54 (17.9\%). These results indicate that soil $\mathrm{Cu}$ can enhance $\mathrm{Cd}$ uptake and accumulation in rice.

\subsection{Accumulation of $\mathrm{P}, \mathrm{Fe}, \mathrm{Cu}$, and $\mathrm{Cd}$ in iron plaques of the six rice genotypes}

Table 4 shows $\mathrm{Cu}$ and $\mathrm{Cd}$ concentrations in rice root surface iron plaques after separate and combined treatment. The accumulation of heavy metals in iron plaques is mainly determined by the genotypes. In addition, soil $\mathrm{Cu}$ treatment $(100 \mathrm{mg} / \mathrm{kg})$ led to $9.9-15.2$ fold higher $\mathrm{Cu}$ concentrations in iron plaques with the highest value in YY-1 and 94D-22. Although adding Cd in soil had no impact on $\mathrm{Cu}$ status, the $\mathrm{Cd} 1.0 \mathrm{mg} / \mathrm{kg}$ was able to induce its own accumulation in iron plaques $(p<0.001)$. Compared to control, $\mathrm{Cd}$ treatment induced $0.5-2.6$ fold higher concentration of the element depending on cultivars. In the combined contamination, $\mathrm{Cu}$ supplement had very minor influence on $\mathrm{Cd}$ concentration in iron plaques. For $\mathrm{P}$ and $\mathrm{Fe}$, concentration of both elements is also varied greatly with cultivars. The $\mathrm{Cd}$ treatment had very little effect on $\mathrm{P}$ and $\mathrm{Fe}$ accumulation, and the $\mathrm{Cu}$ treatment showed very pronounced effect $(p<0.01)$ (Table 5).

\subsection{Transference of $\mathrm{Cu}$ and $\mathrm{Cd}$ from iron plaques to plant tissues}

$F_{\text {shoot }}$ and $F_{\text {root }}$ of $\mathrm{Cu}$ depend on cultivars and are affected by soil $\mathrm{Cu}$ treatment $(p<0.001)$, but not $\mathrm{Cd}$. Under untreated condition, $F_{\text {shoot }}$ and $F_{\text {root }}$ values ranged between 3.2-5.9 and 6.8-10.8 in shoot and root respectively, both value reduced to $0.8-1.5$ and $2.6-3.3$ in $\mathrm{Cu}$ treated soil, and $0.9-1.2$ and $2.4-4.3$ in $\mathrm{Cu}+\mathrm{Cd}$ combined treatment (Fig. 1).

$F_{\text {shoot }}$ and $F_{\text {root }}$ of Cd are also varied with cultivars, and affected by soil application of both $\mathrm{Cd}$ and $\mathrm{Cu}(p<0.001)$. In the untreated soil, the $F_{\text {shoot }}$ and $F_{\text {root }}$ of Cd were 2.3-5.6 
Table 3 Concentrations of $\mathrm{Cd}$ in shoot and root of different rice genotypes grown in $\mathrm{Cu}$ and $\mathrm{Cd}$ contaminated soils $(\mathrm{mg} / \mathrm{kg})$

\begin{tabular}{|c|c|c|c|c|c|c|c|c|}
\hline \multirow[t]{2}{*}{ Genotype } & \multicolumn{4}{|c|}{ Shoot } & \multicolumn{4}{|c|}{ Root } \\
\hline & CK & $\mathrm{Cu}$ & $\mathrm{Cd}$ & $\mathrm{Cu}+\mathrm{Cd}$ & CK & $\mathrm{Cu}$ & $\mathrm{Cd}$ & $\mathrm{Cu}+\mathrm{Cd}$ \\
\hline 94D-22 & $0.19 \pm 0.02$ & $0.30 \pm 0.03$ & $1.28 \pm 0.09$ & $2.03 \pm 0.56$ & $0.37 \pm 0.07$ & $0.63 \pm 0.10$ & $3.17 \pm 0.41$ & $3.56 \pm 0.68$ \\
\hline 94D-54 & $0.24 \pm 0.03$ & $0.28 \pm 0.04$ & $2.01 \pm 0.19$ & $2.41 \pm 0.03$ & $0.57 \pm 0.04$ & $0.61 \pm 0.08$ & $4.52 \pm 0.39$ & $5.33 \pm 0.36$ \\
\hline 94D-64 & $0.35 \pm 0.01$ & $0.38 \pm 0.03$ & $1.87 \pm 0.24$ & $2.30 \pm 0.25$ & $0.55 \pm 0.07$ & $0.66 \pm 0.12$ & $4.42 \pm 0.61$ & $4.40 \pm 0.29$ \\
\hline Gui630 & $0.21 \pm 0.01$ & $0.33 \pm 0.06$ & $1.32 \pm 0.08$ & $2.78 \pm 0.53$ & $0.41 \pm 0.02$ & $0.85 \pm 0.15$ & $3.14 \pm 0.12$ & $6.68 \pm 1.15$ \\
\hline YY-1 & $0.18 \pm 0.01$ & $0.22 \pm 0.04$ & $1.26 \pm 0.10$ & $2.23 \pm 0.35$ & $0.43 \pm 0.03$ & $0.49 \pm 0.09$ & $3.44 \pm 0.29$ & $5.20 \pm 1.11$ \\
\hline KY1360 & $0.13 \pm 0.01$ & $0.32 \pm 0.02$ & $1.46 \pm 0.24$ & $2.12 \pm 0.25$ & $0.27 \pm 0.03$ & $0.67 \pm 0.04$ & $3.76 \pm 0.98$ & $4.45 \pm 0.17$ \\
\hline \multicolumn{9}{|c|}{ Analysis of variance } \\
\hline $\mathrm{Cu}$ & \multicolumn{4}{|c|}{$p<0.001$} & \multicolumn{4}{|c|}{$p<0.001$} \\
\hline $\mathrm{Cd}$ & \multicolumn{4}{|c|}{$p<0.001$} & \multicolumn{4}{|c|}{$p<0.001$} \\
\hline Genotype & \multicolumn{4}{|c|}{ NS } & \multicolumn{4}{|c|}{ NS } \\
\hline $\mathrm{Cu} \times \mathrm{Cd}$ & \multicolumn{4}{|c|}{$p<0.001$} & \multicolumn{4}{|c|}{$p<0.05$} \\
\hline Cu×genotype & \multicolumn{4}{|c|}{ NS } & \multicolumn{4}{|c|}{ NS } \\
\hline $\mathrm{Cd} \times$ genotype & \multicolumn{4}{|c|}{ NS } & \multicolumn{4}{|c|}{ NS } \\
\hline
\end{tabular}

Table 4 Concentrations of $\mathrm{Cu}$ and $\mathrm{Cd}$ in iron plaques of different rice genotypes grown in $\mathrm{Cu}$ and $\mathrm{Cd}$ contaminated soils

\begin{tabular}{|c|c|c|c|c|c|c|c|c|}
\hline \multirow[t]{2}{*}{ Genotype } & \multicolumn{4}{|c|}{ Concentration of $\mathrm{Cu}(\mathrm{mg} / \mathrm{kg})$} & \multicolumn{4}{|c|}{ Concentration of $\mathrm{Cd}(\mathrm{mg} / \mathrm{kg})$} \\
\hline & CK & $\mathrm{Cu}$ & $\mathrm{Cd}$ & $\mathrm{Cu}+\mathrm{Cd}$ & CK & $\mathrm{Cu}$ & $\mathrm{Cd}$ & $\mathrm{Cu}+\mathrm{Cd}$ \\
\hline 94D-22 & $2.68 \pm 0.28$ & $41.07 \pm 7.33$ & $2.42 \pm 0.13$ & $27.21 \pm 3.91$ & $0.05 \pm 0.01$ & $0.11 \pm 0.02$ & $0.15 \pm 0.02$ & $0.16 \pm 0.01$ \\
\hline 94D-54 & $2.04 \pm 0.16$ & $26.81 \pm 1.14$ & $1.99 \pm 0.10$ & $27.89 \pm 1.82$ & $0.05 \pm 0.01$ & $0.07 \pm 0.01$ & $0.09 \pm 0.01$ & $0.22 \pm 0.02$ \\
\hline 94D-64 & $2.72 \pm 0.22$ & $29.57 \pm 2.83$ & $2.61 \pm 0.30$ & $17.13 \pm 1.17$ & $0.06 \pm 0.00$ & $0.03 \pm 0.00$ & $0.19 \pm 0.02$ & $0.10 \pm 0.01$ \\
\hline Gui630 & $2.04 \pm 0.21$ & $22.45 \pm 0.69$ & $1.80 \pm 0.23$ & $27.86 \pm 2.70$ & $0.04 \pm 0.01$ & $0.04 \pm 0.01$ & $0.11 \pm 0.01$ & $0.10 \pm 0.01$ \\
\hline YY-1 & $1.44 \pm 0.12$ & $23.38 \pm 2.55$ & $2.12 \pm 0.12$ & $24.16 \pm 2.85$ & $0.06 \pm 0.01$ & $0.06 \pm 0.00$ & $0.18 \pm 0.03$ & $0.13 \pm 0.03$ \\
\hline KY1360 & $2.28 \pm 0.19$ & $26.58 \pm 1.34$ & $2.83 \pm 0.38$ & $23.65 \pm 3.70$ & $0.06 \pm 0.01$ & $0.04 \pm 0.00$ & $0.16 \pm 0.02$ & $0.07 \pm 0.01$ \\
\hline \multicolumn{9}{|c|}{ Analysis of variance } \\
\hline $\mathrm{Cu}$ & \multicolumn{4}{|c|}{$p<0.001$} & \multicolumn{4}{|c|}{ NS } \\
\hline $\mathrm{Cd}$ & \multicolumn{4}{|c|}{ NS } & \multicolumn{4}{|c|}{$p<0.001$} \\
\hline Genotype & \multicolumn{4}{|c|}{$p<0.01$} & \multicolumn{4}{|c|}{$p<0.001$} \\
\hline $\mathrm{Cu} \times \mathrm{Cd}$ & \multicolumn{4}{|c|}{$p<0.05$} & \multirow{2}{*}{\multicolumn{4}{|c|}{$\begin{array}{c}\text { NS } \\
p<0.001\end{array}$}} \\
\hline Cu×genotype & \multirow{2}{*}{\multicolumn{4}{|c|}{$\begin{array}{l}p<0.05 \\
p<0.05\end{array}$}} & & & & \\
\hline Cd×genotype & & & & & \multicolumn{4}{|c|}{$\begin{array}{c}p<0.001 \\
\text { NS }\end{array}$} \\
\hline
\end{tabular}

Table 5 Concentrations of $\mathrm{P}$ and $\mathrm{Fe}$ in iron plaques of different rice genotypes grown in $\mathrm{Cu}$ and $\mathrm{Cd}$ contaminated soils

\begin{tabular}{|c|c|c|c|c|c|c|c|c|}
\hline \multirow[t]{2}{*}{ Genotype } & \multicolumn{4}{|c|}{ Concentration of $\mathrm{P}(\mathrm{g} / \mathrm{kg})$} & \multicolumn{4}{|c|}{ Concentration of $\mathrm{Fe}(\mathrm{g} / \mathrm{kg})$} \\
\hline & $\mathrm{CK}$ & $\mathrm{Cu}$ & $\mathrm{Cd}$ & $\mathrm{Cu}+\mathrm{Cd}$ & $\mathrm{CK}$ & $\mathrm{Cu}$ & $\mathrm{Cd}$ & $\mathrm{Cu}+\mathrm{Cd}$ \\
\hline 94D-22 & $0.44 \pm 0.10$ & $0.60 \pm 0.05$ & $0.49 \pm 0.00$ & $0.47 \pm 0.14$ & $13.89 \pm 3.58$ & $18.44 \pm 2.20$ & $14.33 \pm 1.37$ & $14.96 \pm 4.50$ \\
\hline 94D-54 & $0.34 \pm 0.04$ & $0.53 \pm 0.05$ & $0.39 \pm 0.03$ & $0.46 \pm 0.46$ & $10.58 \pm 2.09$ & $18.24 \pm 2.46$ & $9.75 \pm 0.74$ & $11.51 \pm 0.71$ \\
\hline $94 \mathrm{D}-64$ & $0.48 \pm 0.03$ & $0.46 \pm 0.03$ & $0.52 \pm 0.05$ & $0.35 \pm 0.00$ & $7.70 \pm 1.23$ & $10.71 \pm 1.21$ & $12.48 \pm 2.81$ & $11.21 \pm 0.72$ \\
\hline Gui630 & $0.33 \pm 0.04$ & $0.32 \pm 0.08$ & $0.41 \pm 0.04$ & $0.38 \pm 0.05$ & $5.62 \pm 0.88$ & $10.84 \pm 3.26$ & $7.14 \pm 0.95$ & $7.74 \pm 2.53$ \\
\hline YY-1 & $0.28 \pm 0.01$ & $0.60 \pm 0.03$ & $0.65 \pm 0.07$ & $0.55 \pm 0.09$ & $9.12 \pm 0.98$ & $19.53 \pm 2.13$ & $13.66 \pm 1.21$ & $13.84 \pm 2.79$ \\
\hline KY1360 & $0.48 \pm 0.07$ & $0.35 \pm 0.04$ & $0.41 \pm 0.08$ & $0.39 \pm 0.04$ & $10.41 \pm 1.12$ & $9.89 \pm 1.63$ & $8.84 \pm 2.46$ & $8.60 \pm 1.08$ \\
\hline \multicolumn{9}{|c|}{ Analysis of variance } \\
\hline $\mathrm{Cu}$ & \multicolumn{4}{|c|}{ NS } & \multicolumn{4}{|c|}{$p<0.01$} \\
\hline $\mathrm{Cd}$ & \multicolumn{4}{|c|}{ NS } & \multicolumn{4}{|c|}{ NS } \\
\hline Genotype & \multicolumn{4}{|c|}{$p<0.01$} & \multicolumn{4}{|c|}{$p<0.001$} \\
\hline $\mathrm{Cu} \times \mathrm{Cd}$ & \multicolumn{4}{|c|}{$p<0.01$} & \multirow{2}{*}{\multicolumn{4}{|c|}{$p<0.01$}} \\
\hline Cu×genotype & \multicolumn{4}{|c|}{$p<0.05$} & & & & NS \\
\hline Cdxgenotype & \multicolumn{4}{|c|}{ NS } & \multicolumn{4}{|c|}{ NS } \\
\hline
\end{tabular}
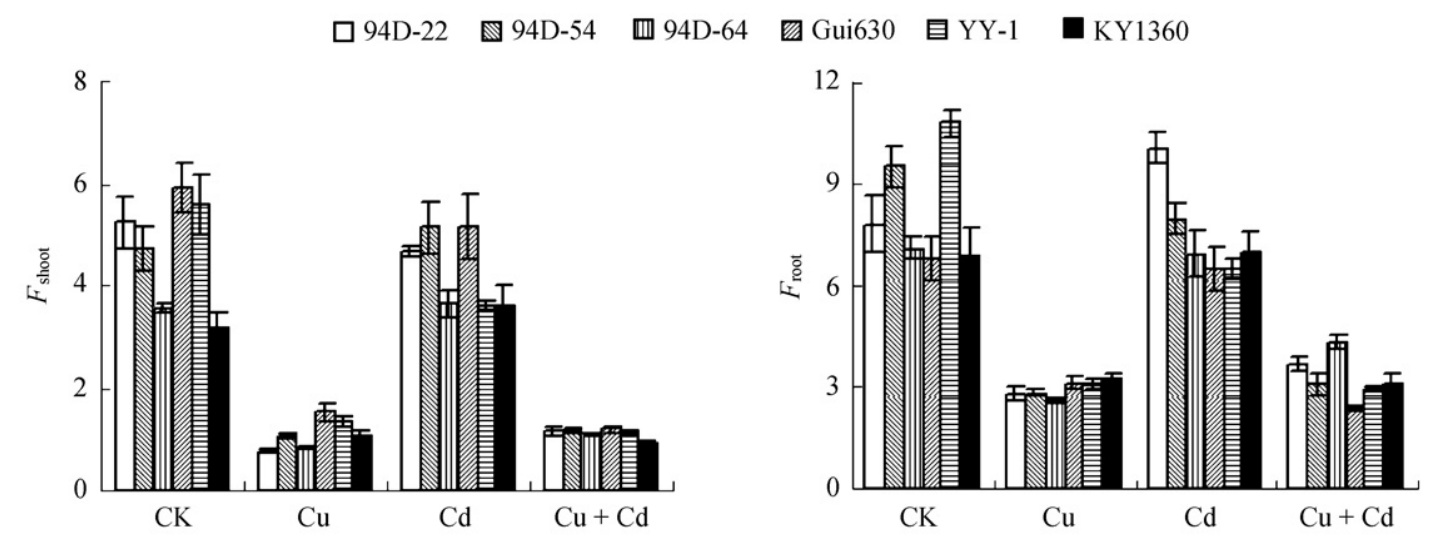

Fig. 1 Transfer factor of $\mathrm{Cu}$ from rice root surface to root and shoot. Bar expresses standard error. 
and 4.8-11.0, respectively. However, $F_{\text {shoot }}$ was as high as

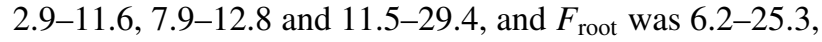
20.5-30.9 and 22.3-62.1 with the treatments of $\mathrm{Cu}, \mathrm{Cd}$, and $\mathrm{Cu}+\mathrm{Cd}$, respectively (Fig. 2).

Under combined contamination, the $F_{\text {root }}$ and $F_{\text {shoot }}$ of $\mathrm{Cd}$ in the range of 22.3-62.1 and 11.5-29.4, however, $F_{\text {root }}$ and $F_{\text {shoot }}$ of $\mathrm{Cu}$ were $2.4-4.3$ and $0.9-1.2$, respectively. These results indicated that $\mathrm{Cd}$ moves more readily than $\mathrm{Cu}$ from iron plaques to root and shoot. The other parameters also showed similar trend.

\section{Discussion}

In rice plants, $\mathrm{Cu}$ concentration was largely dependent on the genotypic cultivars $(p<0.001)$, however, such effect was not observed for $\mathrm{Cd}$. In shoot tissue, the maximum inter-cultivar difference in $\mathrm{Cu}$ concentration was as high as $102.2 \%, 41.6 \%, 46.9 \%$ and $77.5 \%$ in shoot, and $56.5 \%$, $60.1 \%, 116.1 \%$ and $47.4 \%$ in root (Table 2) under the treatments of $\mathrm{CK}, \mathrm{Cu}, \mathrm{Cd}$ and $\mathrm{Cu}+\mathrm{Cd}$, respectively. Similar results have been obtained from other studies. In South Australia, McLaughlin et al. (1994) compared and observed big difference in Cd uptake and accumulation in 14 potato genotypes, for some cultivar tubers $\mathrm{Cd}$ content was in the range of $30-50 \mu \mathrm{g} / \mathrm{kg}$ fresh weight while others are much higher than the national regulation level (50 $\mu \mathrm{g} / \mathrm{kg}$ fresh weight). Based on this observation, it was subsequently proposed to screen for low Cd cultivars to avoid its harmful effect to human health. In another study some high and low accumulation lettuce cultivars were selected after comparing their uptake and accumulation of $\mathrm{Cd}, \mathrm{Cu}, \mathrm{Pb}$ and $\mathrm{Zn}$ (Crews and Davies, 1985).

In the soil-plant system, the interaction between heavy metals can affect their individual function. However, this interaction relationship can be very complex in different soil and plant environments. In this study, soil application of $1.0 \mathrm{mg} / \mathrm{kg} \mathrm{Cd}$ had a negligible effect on $\mathrm{Cu}$ uptake by rice plants, however, $\mathrm{Cu}$ treatment at $100 \mathrm{mg} / \mathrm{kg} \mathrm{Cu}$ greatly enhanced $\mathrm{Cd}$ accumulation $(p<0.001)$. This can be caused by that under the experimental condition, $\mathrm{Cu}$ and $\mathrm{Cd}$ absorb to the soil colloids competitively which result in more $\mathrm{Cd}$ in soil solution available to the plants. Similarly, Fargasova (2001) also found that $\mathrm{Zn}, \mathrm{Cu}$ and $\mathrm{Fe}$ all have some additive effect for $\mathrm{Cd}$ accumulation. On the other hand, $\mathrm{Cd}$ was observed to enhance $\mathrm{Zn}$ and $\mathrm{Cu}$ uptake by mustard cotyledons.

However, different heavy metals can become antagonistic under certain conditions. Fritioff and Greger (2006) studied the accumulation of heavy metal $(\mathrm{Zn}, \mathrm{Cu}, \mathrm{Cd}$ and $\mathrm{Pb}$ ) by aquatic plant Potamogeton natans, and found that all other elements can reduce the $\mathrm{Cd}$ concentration in root, but leaf $\mathrm{Cu}$ concentration was increased. The giant fresh water plant Eriocaulon septangulare, also exhibited the inhibitory effect of Cd uptake by other heavy metals when grown in heavy metal contaminated water zone (Stewart and Malley, 1999). Comparing $\mathrm{Cd}, \mathrm{Pb}$, and $\mathrm{Cu}$ accumulation by three oil crop species (dill, peppermint, and basil) found that peppermint and basil have much lower $\mathrm{Cd}$ level when treated with combined contamination of $\mathrm{Cd}-\mathrm{Pb}, \mathrm{Cd}-\mathrm{Cu}$, and $\mathrm{Cd}-\mathrm{Pb}-\mathrm{Cu}$ compared to $\mathrm{Cd}$ single treatment. This inhibitory effect on $\mathrm{Cd}$ uptake is caused by the competitive binding between $\mathrm{Pb}$ and $\mathrm{Cu}$ with $\mathrm{Cd}$ in the growth medium (Zheljazkov et al., 2006). Similar mode of antagonistic interaction among $\mathrm{Cd}, \mathrm{Cu}$ and $\mathrm{Pb}$ has been observed earlier in different plant species (Kabata-Pendias and Pendias, 1991).

Many studies have shown that $\mathrm{Cd}$ can be easily transferred from root to shoot (Alloway, 1990; Kabata-Pendias and Pendias, 1991). We also noticed that Cd moves more readily from the iron plaques into root and shoot. Raising $\mathrm{Cd}$ level can result in the reduction in the transfer rate of $\mathrm{Cd}$ from root to shoot (Cunningham et al., 1975; Zheljazkov et al., 2006). In contrast, Cd treatment induced high $F_{\text {shoot }}$ and $F_{\text {root }}$ of $\mathrm{Cd}$, and the opposite for the $\mathrm{Cu}$ treatment. The results indicate that high $\mathrm{Cd}$ level enhances $\mathrm{Cd}$ movement from iron plaques to root and shoot, but $\mathrm{Cu}$ did not have similar effect.

Formation of iron plaque is a natural phenomenon on
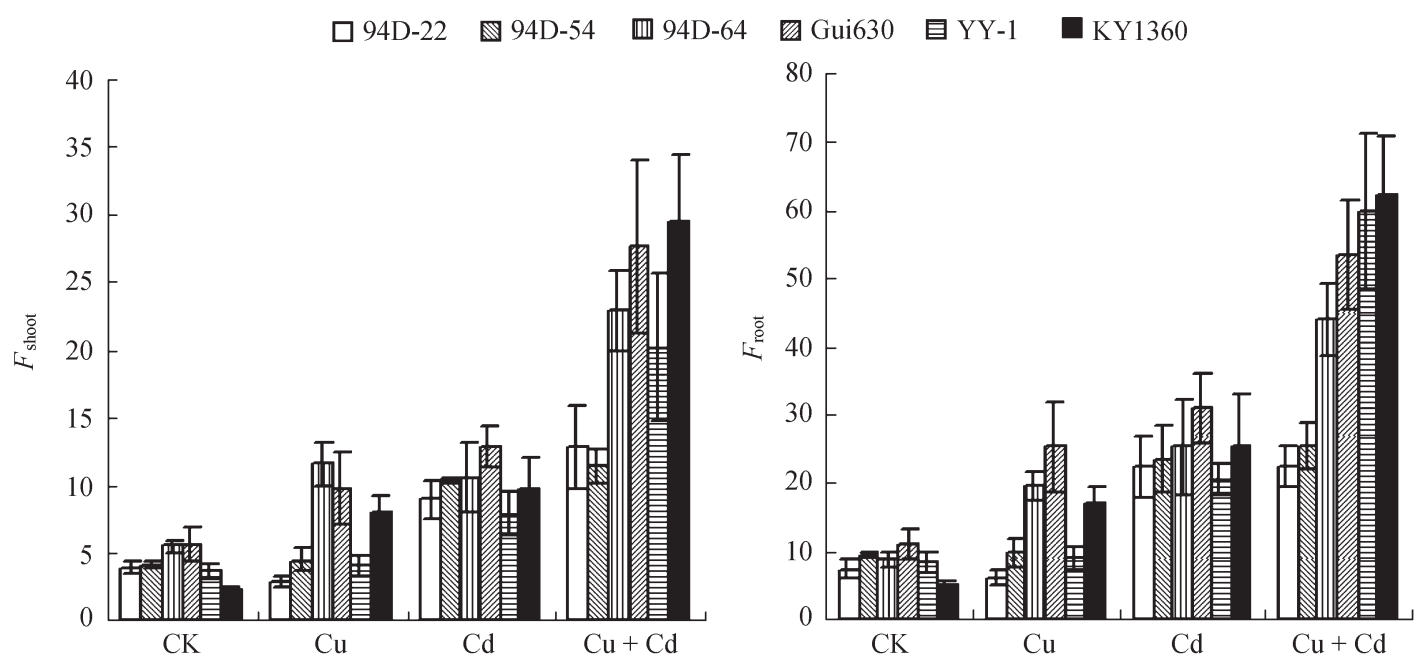

Fig. 2 Transfer factor of Cd from rice root surface to root and shoot. Bar expresses standard error. 
rice root surface. Such structure can also be found in other species such as submerged plants, emerged plants, continental plants in water logging soil, non-flowering plants, conifers. The function of the iron plaques upon heavy metal absorption depends on the elements. In this study, we have found that rice root surface iron plaques can absorb a large amount of $\mathrm{Cu}$ and $\mathrm{Cd}$. The big speciesspecific difference observed in this study might be related to the thickness of the iron plaques. Furthermore, this study also revealed that iron plaques can not reduce the transfer of $\mathrm{Cu}$ and $\mathrm{Cd}$ into plants, moreover, $\mathrm{Cd}$ can be more easily absorbed into root and shoot compared to $\mathrm{Cu}$ (Figs. 1 and 2). Rice with iron plaques can tolerant $\mathrm{Cu}$ and $\mathrm{Ni}$ toxicity stronger than those without such structure. However, iron plaques do not interfere with root uptake of $\mathrm{Cu}$. The reason for the oxide membrane to reduce $\mathrm{Cu}$ toxicity is probably because of the $\mathrm{Cu}$ passivation by $\mathrm{Fe}$ in root cortex.

The iron plaques can absorb and precipitate some heavy metals and thus exclude the elements outside of the plants. In addition, these iron plaques can provide a large amount of Fe to plants competing for the sensitive binding sites with heavy metals. Phragmites communis Trin. forms thicker iron plaques when grown at $\mathrm{pH}$ 6.0, and these plaques can serve as barriers for $\mathrm{Cu}$ and $\mathrm{Mn}$. At $\mathrm{pH} 3.5$, the plaques become thinner and therefore lose the function to block the $\mathrm{Cu}$ and $\mathrm{Mn}$ absorption (Batty et al., 2000). It is also reported that the rice root surface iron plaques can strongly enrich the arsenate by acting as the buffer zone of the toxic ions in the root microenvironment and thereby prevent it from moving into rice root (Liu et al., 2004; Chen et al., 2005).

The fact that iron plaques to absorb metal at varied efficiency possibly related with their physiological and chemical properties. X-ray fluorescent microcopy sectioning profile analysis found that root surface iron plaques mainly consist of oxides of iron and manganese as well as their hydroxides (Batty et al., 2000). These structures have special electro-chemical properties and belong to amphoteric colloid. Activities on the colloidal membrane such as ion exchange, oxidoreduction, organic and inorganic complexation reaction can all change the status of the heavy metals in root zone, and thereby affect their biological toxicity (Otte et al., 1989; St-Cyr and Crowder, 1990).

\section{Conclusions}

The biomass yield is mainly dependent on the genotypes, with the highest from KY1360 and the lowest from 94D-22 and 94D-54. Root growth remained similar upon the treatment of $\mathrm{Cu}$ and $\mathrm{Cd}$. $\mathrm{Cu}$ reduced shoot dry weight.

Both single and combined applications promoted the accumulation of $\mathrm{Cu}$ and $\mathrm{Cd}$ in shoot and root. $\mathrm{Cu}$ induced $\mathrm{Cd}$ accumulation, however, the opposite was not true. Soil supplement with $\mathrm{Cu} / \mathrm{Cd}$ increased their concentrations in rice root surface iron plaques. $\mathrm{Cu}$ significantly affected $\mathrm{Fe}$ but not $\mathrm{Cd}$ concentrations in iron plaques, however, similar result was not observed for $\mathrm{Cu}, \mathrm{P}$ and $\mathrm{Fe}$ upon exposure to Cd treatment.

\section{Acknowledgments}

This work was supported by the National Natural Science Foundation of China (No. 30671204, 40620120436), the Tianjin Specific Fund for Scientific and Technologic innovation (No. 06FZZDSH00900), and the Hi-Tech Research and Development program (863) of China (No. 2007AA061001).

\section{References}

Alexander P D, Alloway B J, Dourado A M, 2006. Genotypic variations in the accumulation of $\mathrm{Cd}, \mathrm{Cu}, \mathrm{Pb}$ and $\mathrm{Zn}$ exhibited by six commonly grown vegetables. Environmental Pollution, 144: 736-745.

Ali N A, Bernal M P, Ater M, 2004. Tolerance and bioaccumulation of cadmium by Phragmites australis grown in the presence of elevated concentrations of cadmium, copper, and zinc. Aquatic Botany, 80: 163-176.

Alloway B J, 1990. Heavy Metals in Soils. Glasgow: Blackie. 321.

Balsberg Påhlsson A M, 1989. Toxicity of heavy metals ( $\mathrm{Zn}, \mathrm{Cu}$, $\mathrm{Cd}, \mathrm{Pb})$ to vascular plants. A literature review. Water, Air and Soil Pollution, 47: 287-319.

Batty L C, Baker A J M, Wheeler B D, Curtis C D, 2000. The effect of $\mathrm{pH}$ and plaque on the uptake of $\mathrm{Cu}$ and $\mathrm{Mn}$ in Phragmites australis (Cav.) Trin ex Steudel. Annals of Botany, 86: 647-653.

Boggess S F, Willavize S, Koeppe D E, 1978. Differential response of soybean genotypes to soil cadmium. Agronomy Journal, 70: 756-760.

Cao Z H, Hu Z Y, Wong M H, 2000. Copper contamination in paddy soils irrigated with wastewater. Chemosphere, 41:36.

Carrier P, Baryla A, Havaux M, 2003. Cadmium distribution and microlocalization in oilseed rape (Brassica napus) after long-term growth on cadmium-contaminated soil. Planta, 216: 939-950.

Chatterjee J, Chatterjee C, 2000. Phytotoxicity of cobalt, chromium and copper in cauliflower. Environmental Pollution, 109: 69-74.

Chen H M, 1996. Heavy Metal Contamination in the Soil-Plant System. Beijing: Scientific Press. 71-85.

Chen Z, Zhu Y G, Liu W J, Meharg A A, 2005. Direct evidence showing the effect of root surface iron plaque on arsenite and arsenate uptake into rice (Oryza sativa L.) roots. New Phytologist, 165: 91-97.

Costa G, Morel J L, 1994. Efficiency of $\mathrm{H}^{+}$-ATPase activity on cadmium uptake by four cultivars lettuces. Journal of Plant Nutrition, 17: 627-637.

Crews H M, Davies B E, 1985. Heavy metal uptake from contaminated soils by six varieties of lettuce (Lactuca sativa L.). Journal of Agricultural Science (Cambridge), 105: 591595.

Cunningham L M, Collins F W, Hutchinson T C, 1975. Physiological and biochemical aspects of cadmium toxicity in soybean. In: Proceedings of the International Conference Heavy Metals in the Environment, Toronto, October 27. 97103.

Das P, Samantaray S, Rout G R, 1997. Studies on cadmium toxicity in plants: A review. Environmental Pollution, 98: $29-36$.

Fargasova A, 2001. Effect of $\mathrm{Cd}$ in combination with $\mathrm{Cu}, \mathrm{Zn}, \mathrm{Pb}$ and $\mathrm{Fe}$ on root prolongation and metal accumulation in the 
roots and cotyledones of mustard (Sinapis alba) seedlings. Plant, Soil and Environment, 47: 97-103.

Florijn P J, van Beusichem M L, 1993. Uptake and distribution of cadmium in maize inbred lines. Plant Soil, 150: 25-32.

Franklin N M, Stauber J L, Lim R P, Petocz P, 2002. Toxicity of metal mixtures to a tropical freshwater alga (Chlorella sp.): The effect of interactions between copper, cadmium, and zinc on metal cell binding and uptake. Environmental Toxicology and Chemistry, 21: 2412-2422.

Fritioff $\AA$, Greger M, 2006. Uptake and distribution of Zn, $\mathrm{Cu}, \mathrm{Cd}$, and $\mathrm{Pb}$ in an aquatic plant Potamogeton natans. Chemosphere, 63: 220-227.

Grant C A, Bailey L D, McLaughlin M J, Singh B R, 1999. Management factors which influence cadmium concentrations in crops. In: Cadmium in Soils and Plants (McLaughlin M J, Singh B R, eds.). Dordrecht: Kluwer Academic Publishers. 151-198.

Hazardous Waste Consultant, 1996. Remediating Soil and Sediment Contaminated with Heavy Metals. The Netherlands: Elsevier Science.

John M K, Laerhoven N, 1976. Differential effects of cadmium on lettuce varieties. Environmental Pollution, 10: 163-173.

Kabata-Pendias A, Pendias H, 1991. Trace Elements in Soils and Plants (2nd ed.). Boca Raton-Ann Arbor-London: CRC Press.

Liu W J, Zhu Y G, Hu Y, Williams P N, Gault A G, Meharg A A et al., 2006. Arsenic sequestration in iron plaque, its accumulation and speciation in mature rice plants (Oryza sativa L.). Environmental Science and Technology, 40: 5730-5736.

Liu W J, Zhu Y G, Smith F A, Smith S E, 2004. Do phosphorus nutrition and iron plaque alter arsenate (As) uptake by rice seedlings in hydroponic culture? New Phytologist, 162: 481-488.

Lu R S, 1999. Agricultural Chemical Analytical Methods of Soil. Beijing: Chinese Agricultural Scientific Press.

McLaughlin M J, Williams G M J, Mckay A, Kirkham R, Gunton J, Jackson K J et al., 1994. Effect of cultivar on uptake of cadmium by potato tubers. Australian Journal of Agricultural Research, 45: 1483-1495.

Meharg A A, Jardine L, 2003. Arsenite transport into paddy rice
(Oryza sativa) roots. New Phytologist, 157: 39-44.

Murakami M, Ae N, Ishikawa S, 2007. Phytoextraction of cadmium by rice (Oryza sativa L.), soybean (Glycine max (L.) Merr.), and maize (Zea mays L.). Environmental Pollution, 145: 96-103.

Oliver D P, Hannam R, Tiller K G, Wilhelm N S, Merry R H, Cozens G D, 1994. The effects of zinc fertilization on cadmium concentration in wheat grain. Journal of Environmental Quality, 23: 705-711.

Otte M L, Rozema J, Koster L, Haarsma M S, Broekman R A, 1989. Iron plaque on roots of Aster tripolium L.: interaction with zinc uptake. New Phytologist, 111: 309-317.

Sarret G, Saumitou-Laprade P, Bert V, Proux O, Hazemann J L, Traverse A S, Marcus M A, Manceau A, 2002. Forms of zinc accumulated in the hyperaccumulator Arabidopsis halleri. Plant Physiology, 130: 1815-1826.

St-Cyr L, Crowder A A, 1990. Manganese and copper in the root plaque of Phragmites australis (Cav.) Trin.ex Steudel. Soil Science, 149: 191-198.

Stewart A R, Malley D F, 1999. Effect of metal mixture $(\mathrm{Cu}$, $\mathrm{Zn}, \mathrm{Pb}$, and $\mathrm{Ni}$ ) on cadmium partitioning in littoral sediments and its accumulation by the freshwater macrophyte Eriocaulon septangulare. Environmental toxicology and chemistry, 18: 436-447.

Tang C, Robson A D, 2000. Cultivar variation in the effect of chlorsulfuron in depressing the uptake of copper in wheat. Plant and Soil, 225: 11-20.

Wang H Y, 2003. Effect of $\mathrm{Cd}, \mathrm{Zn}$, and $\mathrm{Pb}$ compound pollution on celery in a ferric acrisol. Soil and Sediment Contamination, 12: 357-370.

Wu F B, Zhang G P, 2002. Genotypic difference in effect of cadmium on growth and mineral concentrations in barley seedlings. Bulletin of Environmental Contamination and Toxicology, 69: 219-227.

Zhang G P, Fukami M, Sekimoto H, 2000. Genotypic difference in effects of cadmium on growth and nutrition compositions in wheat. Journal of Plant Nutrition, 23: 1337-1350.

Zheljazkov V D, Craker L E, Xing B S, 2006. Effects of Cd, $\mathrm{Pb}$, and $\mathrm{Cu}$ on growth and essential oil contents in dill, peppermint, and basil. Environmental and Experimental Botany, 58: 9-16. 